$\Phi$

\title{
Inhibition of thioacetamide induced liver intoxication and in-vitro antioxidant capacity of the Hugonia mystax
}

\author{
MallikarjunaRao.Talluri ${ }^{1}$, RajanandaSwamy.Tadi ${ }^{2 *}$, Ganga Rao.Battu $^{2}$ \\ ${ }^{1}$ Research Associate, MicGene lab, Visakhapatnam, A.P, India-530003 \\ ${ }^{2}$ Department of Pharmacognosy and Phytochemistry, A.U. College of Pharmaceutical Sciences, \\ Andhra University, Visakhapatnam, A.P, India-530003. \\ *Corresponding author E-mail:rajaphd2015@gmail.com
}

\begin{abstract}
Background: The using of synthetic drugs in adequate manner for the treatments of liver diseases are causes the different side effect. Therefore, there is need to search for new bioactive compounds to control liver diseases. In this point of view, we selected the medicinal plant $H$. mystax to evaluate of its antioxidant and hepatoprotective potentiality and isolation of its constituents, because it has been using in traditional medicine in the treatment of different diseases.

Methods: Different extracts were prepared from H. mystax using maceration extraction process.Antioxidant activity was carried out using standard test procedures on Superoxide, Hydroxyl and DPPH free radicals. Hepatoprotective was tested using Thioacetamide (TAA) induced liver intoxication in rats.

Results: The $H$. mystax extracts were showed dose dependent antioxidant and hepatoprotective activities. Tested extracts of $H$. mystax have more activity on hydroxyl free radical than superoxide and DPPH radicals and among all extracts hydroalcoholic extract showed more activity. The extracts of $H$. mystax significantly restored the altered biochemical parameters due to TAA induced liver intoxication and hydroalcoholic extract exhibited more significant activity. So, the hydroalcoholic extract was used for the isolation of phytochemical constituents through column chromatography and isolated HM-1 and HM-2 compounds and are identified as stigmasterol and $\beta$-sitosterol Conclusion: From the results of the study, it could be conclude that H. mystax have the capacity in reduction of free radicals and normalization of liver function when it damage due to different liver intoxications and further research is need to evaluate more pharmacological activities and in isolation of most active bioactive compounds from H. mystax.
\end{abstract}

Keywords: H. mystax; Aerial Parts; Antioxidant Activity; Thioacetamide; Hepatoprotective Activity.

\section{Introduction}

Liver is one of the main functional organ in human body, plays an important role in metabolic processes like metabolism of lipids, proteins, and carbohydrates (Senguptaet al., 2011; Alqasoumiet al., 2009; Jamshidzadeh and Nikmahad, 2006). Because of its' multi-dimensional functions, it is major organ easily effect by many diseases. The liver diseases may cause due to the Alcohol consumption, Hepatitis virus, Liver transplantations, Obesity and Non-Alcohol related fatty liver diseases etc. The use of synthetic drugs (Steroids, Inhalants) for the treatments of liver diseases in inadequate manner causes different side effects on their long-term usage. Therefore, there is need to search new fighting strategies to control liver diseases with less or lack of side effects and low cost because the present drugs available in the market in the treatment of diseases are expensive. The medicinal plants are source for new drugs since the ancient times to treat different diseases around world (Bandaranayake, 2002; Ashok et al., 2001, Ganga Rao et al., 2013). But, till now only a small percentage has been investigated phytochemically and submitted to pharmacological screening and large number of plants are unexplored for source of powerful drugs (Thomson, 1978; Stockwell, 1988; Clark and Hufford, 1993). The researchers are turning from manufacturing of synthetic drugs to herbal extracts to isolate new drug molecules have natural origin and synthesis of those drugs derivatives which have less side effects from traditionally used medicinal plants by tribes or societies across the globe (Kroschwitz and Howe-Grant, 1992; Newman et al., 2000; Balandrin et al., 1985). Considering the unbounded potentiality of plants as sources for new drugs, a systematic investigation was undertaken to screen the phytochemical analysis, Antioxidant and hepatoprotective activity of Hugonia mystax aerial parts. The plant $H$. mystax has been using in traditional medicine i.e. useful in fever, verminosis and vitiated conditions of vata, externally as a past for inflammations and used swelling due to viper bite (Nambiar, 1995; Santapau and Henry, 1983; Pullaiah and Chennaiah, 1997; Padel et al., 2010; RajanandaSwamy et al., 2016).

\section{Material and methods}

\subsection{Chemicals and drugs}

Silymarin, Thioacetamide (TAA) and 1, 1- diphenyl-2picrylhydrazyl was purchased from Sigma chemicals, USA. Nitrobluetetrozolium was purchased from Sisco Research Laboratories Pvt Ltd., Mumbai. Riboflavin was purchased from LobaChemiePvt Ltd., Bombay. Serum Glutamate Oxaloacetate Transaminase (SGOT), Serum Glutamate Pyruvate Transaminase (SGPT), Serum Alkaline Phosphatase (ALP), Serum Total bilirubin (T.Bil) and Serum total protein (TP) kits were purchased from 
Span diagnostics Ltd, Gujarat, India. All other chemicals used were of analytical grade.

\subsection{Collection of plant material and preparation of ex- tracts}

The plant material was collected near Indira Gandhi Zoological park, Visakhapatnam, Andhra Pradesh, India. The authentication of the plant was done by Rtd. Prof. M. Venkaih, Department of Botany, Andhra University, Visakhapatnam. Shade dried powdered plant was extracted using maceration process with hexane, ethyl acetate, and hydroalcoholic (ethanol (70\%v/v)) separately and collected solvents were concentrated to dryness under vacuum using rotavapour.

\subsection{Animals}

Albino rats of either sex weighing between 180-200gm were obtained from M/s. Mahavir Enterprises, Hyderabad. The animals were housed under controlled environmental conditions (temperature of $22 \pm 1^{\circ} \mathrm{Cwith}$ an alternating $12 \mathrm{hr}$ light-dark cycle and relative humidity of $60 \pm 5 \%$ ), one week before the start and also during the experiment. They were fed with standard laboratory diet supplied by M/s. Rayans biotechnologies Pvt. Ltd., Hyderabad, and water ad labium during experiment. Food was withdrawn $12 \mathrm{hr}$ before the terminating experiment and water was allowed adlibitum.

\subsection{Acute toxicity studies}

Acute toxicity study was conducted according OECD Guide lines No.423. The experimental protocol was approved by institutional animal ethical committee of Regd. No. 516/01/A/CPCSEA, University College of Pharmaceutical Sciences, Andhra University, Visakhapatnam. After fasting overnight, mices were administered with extracts of $H$. mystax in a single dose up to the highest dose of $2000 \mathrm{mg} / \mathrm{kg}$ orally. The animals were observed continuously for $1 \mathrm{~h}$ and then hourly for $6 \mathrm{~h}$ and finally after every $24 \mathrm{~h}$ up to 15 days for any toxicological symptoms or mortality.

\subsection{In-vitro antioxidant activity}

The extracts of $H$. mystax screened for free radical scavenging activity against Superoxide radical, Hydroxyl and DPPH radicals at different concentrations. The Percentage Inhibition and 50\% Inhibition Concentration's $\left(\mathrm{IC}_{50}\right)$ were calculated.

\subsubsection{Superoxide radical scavenging activity}

Superoxide scavenging activity of the plant extract was determined by McCord \& Fridovich method (1969), this depends on light induced superoxide generation by riboflavin and the corresponding reduction of nitrobluetetrazolium.

\subsubsection{Hydroxyl radical scavenging activity}

Hydroxyl radical scavenging activity is commonly used to evaluate the free radical scavenging effectiveness of various antioxidant substances (Elizabeth and Rao, 1990). Hydroxyl radical scavenging activity was measured by studying the competition between deoxyribose and the extracts for hydroxyl radicals generated from the $\mathrm{Fe} 2+/ \mathrm{EDTA} / \mathrm{H}_{2} \mathrm{O}_{2}$ system (Fenton reaction). The hydroxyl radical attacks deoxyribose, which eventually results in the formation of thiobarbituric acid reacting substances (TBARS).

\subsubsection{DPPH radical scavenging activity}

The scavenging activity for DPPH free radicals was measured according to the standard procedure (Braca et al., 2003). In DPPH assay method is based on the reduction of alcoholic DPPH solution (dark blue in colour) in the presence of a hydrogen donating antioxidant converted to the non-radical form of yellow colored diphenylpicrylhydrazine. Lower the absorbance higher the free radical scavenging activity (Anita Murali et al., 2011).

\subsubsection{Calculation of percentage inhibition}

The percentage inhibition of superoxide production by the extract was calculated using the formula:

Inhibitory ratio $=\left(\right.$ Ao- $\left.\mathrm{A}_{1}\right) \times 100 / \mathrm{A}_{0}$

Where, $\mathrm{A}_{0}$ is the absorbance of control; $\mathrm{A}_{1}$ is the absorbance with addition of plant extract/ ascorbic acid.

\subsubsection{Calculation of $50 \%$ inhibition concentration}

The optical density obtained with each concentration of the extract/ascorbic acid was plotted taking concentration on X-axis and percentage inhibition on Y-axis. The graph was extrapolated to find the $50 \%$ inhibition concentration of extract/ ascorbic acid.

\subsection{Evaluation of hepatoprotective activity on TAA in- duced hepatotoxicity in rats}

Thioacetamide induced hepatotoxicity in rats model was used for evaluation of hepatoprotective activity for the selected plant extracts. Animals were divided into twelve groups consisting of six rats in each group (Mangipudy et al., 1995; Dorğru-Abbasoğlu et al., 2000). The animals of group I served as control (vehicle) were given only Saline ( $2 \mathrm{ml} / \mathrm{kg}$ b.w., per orally) for seven days. The animals of group II were administered with Thioacetamide (TAA, $50 \mathrm{mg} / \mathrm{kg}$ b. w., s.c.) as a $2 \% \mathrm{w} / \mathrm{v}$ solution in water for injection on day 1 st and then normal saline for 21 days. The animals of group III were administered with TAA (50 mg/kg b. w., s.c.) as a $2 \%$ w/v solution in water for injection on day 1 st and then silymarin (25mg/kg per day, p. o.) for 21 days. Group IV, V and VI animals were administered with TAA $(50 \mathrm{mg} / \mathrm{kg} \mathrm{b}$.w., s.c.) as a $2 \% \mathrm{w} / \mathrm{v}$ solution in water for injection on day 1 st and then Hydro alcoholic extract of $H$. mystax $(125,250$ and $500 \mathrm{mg} / \mathrm{kg}$ respectively) for 21 days. Group VII, VIII and IX animals were administered with TAA $(50 \mathrm{mg} / \mathrm{kg} \mathrm{b}$.w., s.c.) as a $2 \% \mathrm{w} / \mathrm{v}$ solution in water for injection on day 1 st and then Ethyl acetate extract of $H$. mystax $(125,250$ and $500 \mathrm{mg} / \mathrm{kg}$ respectively) for 21 days and finally for group X, XI and XII animals were administered with TAA (50 $\mathrm{mg} / \mathrm{kg} \mathrm{b}$.w., s.c.) as a $2 \% \mathrm{w} / \mathrm{v}$ solution in water for injection on day 1 st and Hexane extract of $H$. mystax $(125,250$ and $500 \mathrm{mg} / \mathrm{kg}$ respectively) for 21 days. Rats of all the groups were anaesthetized by chloroform, $48 \mathrm{hr}$ after the TAA administration. The blood was collected from retro-orbital plexus. The blood was collected from rats were sacrificed and the collected blood samples were immediately centrifuged at $2400 \mathrm{rpm}$ for 15 minutes. When serum clearly separated out, the serum was analyzed for AST (SGOT), ALT (SGPT), ALP, total bilirubin and total protein levels using commercial diagnostics reagent kits and Auto analyzer.

\subsection{Isolation of phytoconstituents (compounds)}

The selected plant extracts (Hexane, Ethyl acetate and hydroalcoholic) on TLC over showed different spots with different retention factor $\left(\mathrm{R}_{\mathrm{f}}\right)$ values, but on the basis of biological activities (Antioxidant and Hepatoprotective and Antibacterial (RajanadaSwamy et al., 2016), less phytochemical works was reports and availability of the extract quantity hydroalcoholic extract of $H$. mystax was used for separation of compounds using column chromatography.

\section{Results}

\subsection{Antioxidant activity of hugoniamystax}

In the present study, hydroalcoholic, ethyl acetate and hexane extracts of $H$. mystax were found to possess concentration depend- 
ent scavenging activity on tested free radicals. The results were given in Table 1 and Fig 1.

Table 1: $50 \%$ Inhibition Concentrations $\left(\mathrm{IC}_{50}\right)$ of Different Extracts of H. mystax against Superoxide, Hydroxyl and DPPH Radicals.

\begin{tabular}{llll}
\hline \multirow{2}{*}{ Name of the extract } & $\begin{array}{l}50 \% \text { Inhibition Conc }\left(\mathrm{IC}_{50}\right) \\
\text { Superoxide radical }\end{array}$ & Hydroxyl radical & DPPH radical \\
\hline Hydroalcoholic extract & $219.58 \pm 0.52$ & $283.4 \pm 0.40$ & $277.36 \pm 0.56$ \\
Ethyl acetate extract & $281.36 \pm 1.22$ & $299.26 \pm 0.18$ & $208.66 \pm 0.48$ \\
Hexaneextract & $429.62 \pm 0.42$ & $235.84 \pm 0.92$ & $335.82 \pm .86$ \\
Ascorbic acid & $54.4 \pm 1.1$ & $68.00 \pm 1.3$ & $22.0 \pm 0.5$ \\
\hline
\end{tabular}

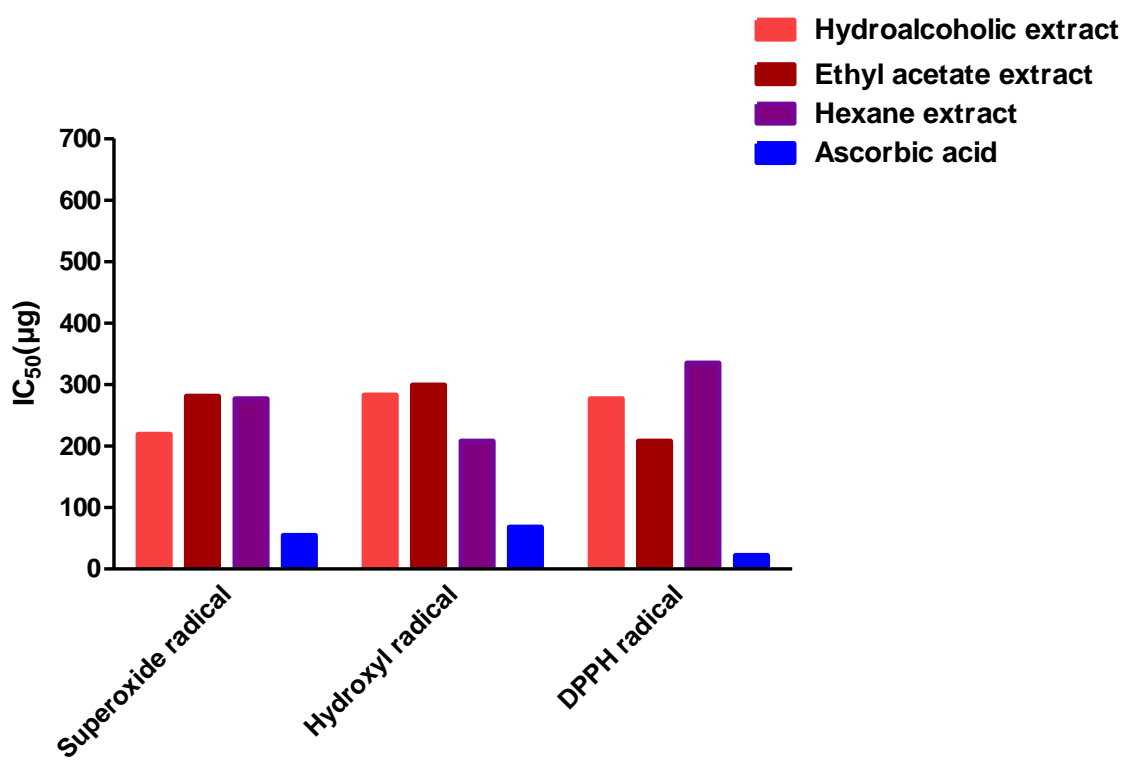

Fig. 1: 50\% Inhibition Concentrations ( $\left.\mathrm{IC}_{50}\right)$ of Different Extracts of $H$. mystax Against Superoxide, Hydroxyl and DPPH Radicals

The mean $\mathrm{IC}_{50}$ values for superoxide radical of hydroalcoholic, ethyl acetate and hexane extracts of $H$. mystax were found to be $219.58 \pm 0.52 \mu \mathrm{g}, 281.36 \pm 1.22 \mu \mathrm{g}$ and $429.62 \pm 0.42 \mu \mathrm{g}$ respectively. The mean $\mathrm{IC}_{50}$ value of ascorbic acid was found to be $54.4 \pm 1.1 \mu \mathrm{g}$. Among all extracts hydroalcoholic extract at a concentration of $640 \mu \mathrm{g}$ showed the better scavenging activity on superoxide free radical i.e. $70.3 \pm 1.2 \%$.

The mean $\mathrm{IC}_{50}$ values for hydroxyl radical of hydroalcoholic, ethyl acetate and hexane extracts of $H$. mystax were found to be $283.4 \pm 0.40 \mu \mathrm{g}, 299.26 \pm 0.18 \mu \mathrm{g}$ and $235.84 \pm 0.92 \mu \mathrm{g}$ respectively. The mean $\mathrm{IC}_{50}$ value of ascorbic acid was found to be $68.00 \pm 1.3 \mu \mathrm{g}$. Among all extracts hexane extract at a concentration of $640 \mu \mathrm{g}$ showed the better scavenging activity on hydroxyl free radical i.e. $66.8 \pm 0.16 \%$.

The mean $\mathrm{IC}_{50}$ values for DPPH radical of hydroalcoholic, ethyl acetate and hexane extracts of $H$. mystax were found to be $277.36 \pm 0.56 \mu \mathrm{g}, 208.66 \pm 0.48 \mu \mathrm{g}$ and $335.82 \pm .86 \mu \mathrm{g}$ respectively. The mean $\mathrm{IC}_{50}$ value of ascorbic acid was found to be $22.0 \pm 0.5 \mu \mathrm{g}$. Among all extracts ethyl acetate extract at a concentration of $640 \mu \mathrm{g}$ showed the better scavenging activity on DPPH free radical i.e. $68.4 \pm 0.48 \%$.

The selected plant extracts showed more activity on hydroxyl free radical than other two radicals. The order of activity in the following manner: ascorbic acid >hydroalcoholic extract > ethyl acetate extract> hexane extract.

\subsection{Acute toxicity studies}

There were no visible sign of toxicity and mortality after oral administration of single dose $(2000 \mathrm{mg} / \mathrm{kg})$ of selected medicinal plant extracts. The results (Table 2 ) clearly indicated non toxicity/safety of the extracts at a dose of $2000 \mathrm{mg} / \mathrm{kg}$. Hence there is no lethal dosage $\left(\mathrm{LD}_{50}\right)$ and all the tested extracts were considered safe and non toxic. This prompted the author to select different doses of selected three plants extracts for evaluation of biological activities.
Table 2: Acute Toxicity of $H$. mystax Extracts Administered by Orally to Mices.

\begin{tabular}{lllll}
\hline Doses $(\mathrm{mg} / \mathrm{kg})$ & Sex & $\mathrm{D} / \mathrm{T}$ & $\begin{array}{l}\text { Mortality laten- } \\
\text { cy }\end{array}$ & $\begin{array}{l}\text { Toxic symp- } \\
\text { toms }\end{array}$ \\
\hline $2000(\mathrm{H} . \mathrm{m} \mathrm{EtO}-$ & $\mathrm{M}$ & $0 / 6$ & - & None \\
HE) & $\mathrm{M}$ & $0 / 6$ & - & None \\
$2000(\mathrm{H} . \mathrm{m} \mathrm{EAE})$ & $\mathrm{M}$ & $0 / 6$ & - & None \\
\hline
\end{tabular}

$\mathrm{D} / \mathrm{T}=$ dead/treated rats; none $=$ no toxic symptoms during the observation period; mortality latency $=$ time to death (in hours) after administered by orally.

H. m EtOHE: H. mystax Hydroalcoholic extract; H. m EAE: H. mystax Ethyl acetate extract; H. m HE: H. mystax Hexane extract.

\subsection{Hepatoprotective activity}

The increase in various biochemical parameters like SGOT, SGPT, ALP, TP and TBIL levels were recorded due to TAA. The effects of test extracts of all the plants were compared against the standard drug silymarin which was orally administered to the rats at a dose of $25 \mathrm{mg} / \mathrm{kg}$ body weight. The doses of the extracts were determined from the drug tolerance studies and the respective plant extracts were accordingly administered. Administration of the extracts of selected medicinal plants orally in doses of 125 , 250 and $500 \mathrm{mg} / \mathrm{kg}$ followed by TAA after administration of the test sample prevented the rise of SGOT, SGPT, ALP, TP and TBIL levels and percentage protection of the extracts were recorded. The tested extracts against Thioacetamide intoxication, hydroalcoholic extracts of selected plants showed maximum hepatoprotective activity in terms of reduction in the elevated levels of serum biochemical parameters. The ethyl acetate extract, hexane extract follow next in order.

Group I was treated with vehicle showed no significant changes in the biomarkers of liver enzymes (AST (SGOT), ALT (SGPT), ALP, total bilirubin and total protein) levels. Group II was treated TAA there is significant changes in levels of biomarker enzymes (Table 3). The animals of group III were administered with TAA $(50 \mathrm{mg} / \mathrm{kg} \mathrm{b}$. w., s.c.) as a $2 \% \mathrm{w} / \mathrm{v}$ solution in water for injection 
on day 1 st and then silymarin $(25 \mathrm{mg} / \mathrm{kg}$ per day, p. o.) for 21 days. There is significant changes in biomarker enzymes levels compared to group II rats enzymes levels (Table 3) and the percentage protection offered by the silymarin against the changes in AST
(SGOT), ALT (SGPT), ALP, total bilirubin and total protein levels were $96.24 \%, 95.25 \%, 93.90 \%, 97.83 \%$ and $96.14 \%$ respectively (Table 4).

Table 3: Enzymes Levels of the Animals Due to the Effect of $H$. mystax Extracts

\begin{tabular}{|c|c|c|c|c|c|c|c|c|c|c|c|c|}
\hline \multirow{3}{*}{. } & \multicolumn{12}{|c|}{ Name of the drug } \\
\hline & \multirow[t]{2}{*}{$\begin{array}{l}\text { Normal } \\
\text { (Drug } \\
\text { Vehicle) }\end{array}$} & \multirow[t]{2}{*}{$\begin{array}{l}\text { Thio- } \\
\text { acetamide }\end{array}$} & \multirow{2}{*}{$\begin{array}{l}\text { Sylimarin }(\mathrm{mg} / \mathrm{kg} \\
\text { b.w) } \\
25\end{array}$} & \multicolumn{3}{|c|}{$\begin{array}{l}\text { H. mystax Hexane } \\
\text { extract } \\
(\mathrm{mg} / \mathrm{kg} \mathrm{b} . \mathrm{w})\end{array}$} & \multicolumn{3}{|c|}{$\begin{array}{l}\text { H. mystax Ethyl acetate ex- } \\
\text { tract } \\
(\mathrm{mg} / \mathrm{kg} \text { b.w) }\end{array}$} & \multicolumn{3}{|c|}{$\begin{array}{l}\text { H. mystax } 70 \% \text { ethanol extract } \\
(\mathrm{mg} / \mathrm{kg} \text { b.w) }\end{array}$} \\
\hline & & & & 125 & 250 & 500 & 125 & 250 & 500 & 125 & 250 & 500 \\
\hline SGOT & $96.17 \pm$ & $330.5 \pm$ & $87 \pm$ & $249.5 \pm$ & $221.5 \pm$ & $195.3 \pm$ & $233.3 \pm$ & $210.2 \pm$ & $187.67 \pm$ & $229.5 \pm$ & $199 \pm$ & $152.17 \pm$ \\
\hline (U/L) & 6.97 & 6.53 & 2.83 & 5.24 & 4.46 & 4.46 & 4.27 & 3.13 & 5.32 & 6.25 & 5.87 & 2.48 \\
\hline SGPT & $56 \pm$ & $173 \pm$ & $50.17 \pm$ & $137.3 \pm$ & $122.5 \pm$ & $106.5 \pm$ & $129.8 \pm$ & $116.5 \pm$ & $102 \pm$ & $120 \pm$ & $105.17 \pm$ & $82.5 \pm$ \\
\hline (U/L) & 3.58 & 5.22 & 4.96 & 3.93 & 4.64 & 4.09 & 2.93 & 5.82 & 3.95 & 4.15 & 2.79 & 1.87 \\
\hline (U/L) & 2.59 & 21.60 & 5.10 & 3.88 & 5.97 & 4.59 & 7.01 & 3.89 & 5.09 & 4.93 & 6.53 & 6.62 \\
\hline \multirow{2}{*}{$\begin{array}{l}\text { Total } \\
\text { bilirubin } \\
\text { (mg/dl) }\end{array}$} & $0.17 \pm$ & $2.123 \pm$ & $0.13 \pm$ & $1.75 \pm$ & $1.4 \pm$ & $1.12 \pm$ & $1.65 \pm$ & $1.38 \pm$ & $1.07 \pm$ & $1.57 \pm$ & $1.27 \pm$ & $0.93 \pm$ \\
\hline & 0.01 & 0.27 & 0.05 & 0.22 & 0.28 & 0.20 & 0.22 & 0.30 & 0.20 & 0.23 & 0.16 & 0.22 \\
\hline \multirow{2}{*}{$\begin{array}{l}\text { Total } \\
\text { protein } \\
(\mathrm{g} / \mathrm{dl})\end{array}$} & $7.40 \pm$ & $4.87 \pm$ & $7.50 \pm$ & $5.43 \pm$ & $5.78 \pm$ & $6.22 \pm$ & $5.4 \pm$ & $5.78 \pm$ & $6.25 \pm$ & $5.5 \pm$ & $5.95 \pm$ & $6.43 \pm$ \\
\hline & 0.46 & 0.78 & 0.37 & 0.29 & 0.29 & 0.30 & 0.23 & 0.29 & 0.28 & 0.33 & 0.44 & 0.27 \\
\hline
\end{tabular}

Table 4: Percentage (\%) Protection on Enzymes Levels Due To the Effect of $H$. mystax Extracts at Different Doses on TAA-Induced Liver Toxicity

\begin{tabular}{|c|c|c|c|c|c|c|c|c|c|c|c|c|c|c|c|}
\hline \multirow[b]{2}{*}{$\begin{array}{l}\text { Name of } \\
\text { the } \\
\text { extract }\end{array}$} & \multicolumn{3}{|c|}{$\begin{array}{l}\text { Amount of the extract } \\
125 \mathrm{mg} / \mathrm{kg} \mathrm{b} . \mathrm{w}\end{array}$} & \multirow[b]{2}{*}{$\begin{array}{l}\text { Total } \\
\text { biliru- } \\
\text { bin } \\
(\mathrm{mg} / \mathrm{dl})\end{array}$} & \multirow[b]{2}{*}{$\begin{array}{l}\text { Total } \\
\text { pro- } \\
\text { tein } \\
(\mathrm{g} / \mathrm{dl})\end{array}$} & \multicolumn{3}{|c|}{$250 \mathrm{mg} / \mathrm{kg}$ b.w } & \multirow[b]{2}{*}{$\begin{array}{l}\text { Total } \\
\text { biliru- } \\
\text { bin } \\
(\mathrm{mg} / \mathrm{dl})\end{array}$} & \multirow[b]{2}{*}{$\begin{array}{l}\text { Total } \\
\text { pro- } \\
\text { tein } \\
(\mathrm{g} / \mathrm{dl})\end{array}$} & \multicolumn{2}{|c|}{$500 \mathrm{mg} / \mathrm{kg}$ b.w } & \multirow[b]{2}{*}{$\begin{array}{l}\text { ALP } \\
(\mathrm{U} / \mathrm{L} \\
)\end{array}$} & \multirow[b]{2}{*}{$\begin{array}{l}\text { Total } \\
\text { biliru- } \\
\text { bin } \\
(\mathrm{mg} / \mathrm{dl})\end{array}$} & \multirow[b]{2}{*}{$\begin{array}{l}\text { Total } \\
\text { pro- } \\
\text { tein } \\
(\mathrm{g} / \mathrm{dl})\end{array}$} \\
\hline & $\begin{array}{l}\text { SGO } \\
\mathrm{T} \\
(\mathrm{U} / \mathrm{L})\end{array}$ & $\begin{array}{l}\text { SGP } \\
\mathrm{T} \\
(\mathrm{U} / \mathrm{L})\end{array}$ & $\begin{array}{l}\text { ALP } \\
(\mathrm{U} / \mathrm{L} \\
)\end{array}$ & & & $\begin{array}{l}\text { SGO } \\
\mathrm{T} \\
(\mathrm{U} / \mathrm{L})\end{array}$ & $\begin{array}{l}\text { SGP } \\
\mathrm{T} \\
(\mathrm{U} / \mathrm{L})\end{array}$ & $\begin{array}{l}\text { ALP } \\
(\mathrm{U} / \mathrm{L} \\
)\end{array}$ & & & $\begin{array}{l}\text { SGO } \\
\mathrm{T} \\
(\mathrm{U} / \mathrm{L})\end{array}$ & $\begin{array}{l}\text { SGP } \\
\mathrm{T} \\
(\mathrm{U} / \mathrm{L})\end{array}$ & & & \\
\hline $\begin{array}{l}\text { Sylimari } \\
\mathrm{n}\end{array}$ & 96.24 & 95.25 & $\begin{array}{l}93.9 \\
0\end{array}$ & 97.83 & 96.14 & 96.24 & 95.25 & $\begin{array}{l}93.9 \\
0\end{array}$ & 97.83 & 96.14 & 96.24 & 95.25 & $\begin{array}{l}93.9 \\
0\end{array}$ & 97.83 & 96.14 \\
\hline $\begin{array}{l}\text { Hydro- } \\
\text { alcoholic }\end{array}$ & 43.10 & 45.30 & $\begin{array}{l}34.5 \\
2\end{array}$ & 28.55 & 26.28 & 56.12 & 57.98 & $\begin{array}{l}50.7 \\
8\end{array}$ & 43.93 & 42.75 & 76.10 & 77.35 & $\begin{array}{l}68.6 \\
5\end{array}$ & 61.03 & 61.86 \\
\hline $\begin{array}{l}\text { Ethyl } \\
\text { acetate }\end{array}$ & 41.47 & 36.89 & $\begin{array}{l}32.2 \\
1\end{array}$ & 24.27 & 21.67 & 51.35 & 48.29 & $\begin{array}{l}43.2 \\
3\end{array}$ & 37.95 & 36.17 & 60.95 & 60.68 & $\begin{array}{l}54.6 \\
6\end{array}$ & 54.19 & 54.61 \\
\hline Hexane & 34.57 & 30.48 & $\begin{array}{l}27.5 \\
8 \\
\end{array}$ & 19.15 & 22.33 & 46.51 & 43.16 & $\begin{array}{l}38.2 \\
5 \\
\end{array}$ & 37.09 & 36.17 & 57.68 & 56.84 & $\begin{array}{l}51.3 \\
8\end{array}$ & 51.62 & 53.29 \\
\hline
\end{tabular}

Groups IV, V and VI were treated with hydroalcoholic extract of $H$. mystax orally at doses of $125 \mathrm{mg} / \mathrm{kg}, 250 \mathrm{mg} / \mathrm{kg}$ and $500 \mathrm{mg} / \mathrm{kg}$ b.w. The percentage protection produced by the extract on the enhancement of AST (SGOT), ALT (SGPT), ALP, total bilirubin and total protein levels were $43.10 \%, 45.30 \%, 34.52 \% 28.55 \%$ and $26.28 \%, 56.12 \%, 57.98 \%, 50.78 \%, 43.93 \%$ and $42.75 \%$, $76.10 \%, 77.35 \%, 68.65 \% 61.03 \%$ and $61.86 \%$ respectively.

Groups VII, VIII and IX were treated with ethyl acetate extract of $H$. mystax orally at doses of $125 \mathrm{mg} / \mathrm{kg}, 250 \mathrm{mg} / \mathrm{kg}$ and $500 \mathrm{mg} / \mathrm{kg}$ b.w. The percentage protection produced by the extract on the enhancement of AST (SGOT), ALT (SGPT), ALP, total bilirubin and total protein levels were $41.47 \%, 36.89 \%, 32.21 \% 24.27 \%$ and $21.67 \%, 51.35 \%, 48.29 \%, 43.23 \% 37.95 \%$ and $36.17 \%, 60.95 \%$, $60.68 \%, 54.66 \% 54.19 \%$ and $54.61 \%$ respectively.

Groups X, XI and XII were treated with hexane extract of $H$. mystax orally at doses of $125 \mathrm{mg} / \mathrm{kg}, 250 \mathrm{mg} / \mathrm{kg}$ and $500 \mathrm{mg} / \mathrm{kg}$ b.w. The percentage protection produced by the extract on the enhancement of AST (SGOT), ALT (SGPT), ALP, total bilirubin and total protein levels were $34.57 \%, 30.48 \%, 27.58 \% 19.15 \%$ and $22.33 \%, 46.51 \%, 43.16 \%, 38.25 \% 37.09 \%$ and $36.17 \%$, $57.68 \%, 56.84 \%, 51.38 \% 51.62 \%$ and $53.29 \%$ respectively.

\subsection{Isolation of compounds form hydroalcoholic extract}

Column chromatography was carried out for the hydroalcoholic extract using different combination of solvents polarity increasing from hexane (100\%) to Ethyl acetate (100\%) and then to Ethanol. We isolated the compounds HM-1 and HM-2 at different concentrations.

\subsubsection{Structural elucidation and characterization of com- pound HM-1}

This compound was obtained from hexane: ethyl acetate (95:05) fractions as color less crystalline solid was identified as Stigmasterol by spectrosopic analysis. The molecular formula is $\mathrm{C}_{29} \mathrm{H}_{48} \mathrm{O}$. The melting point was recorded at $140^{\circ} \mathrm{C}$. The IR spectrum showed absorption bands at 3424, 2960,2937,2867,1464 and $1381 \mathrm{~cm}^{-1}$ (Fig 2). This compound showed very strong color reaction with sulphuric acid indicating its steroidal nature.

The ${ }^{1} \mathrm{H}$ NMR (Fig 3) spectrum of the compound MH-1 revealed a one-proton multiplet at $\delta 3.23$, the position and multiplicity of which was indicative of $\mathrm{H}-3$ of the steroidal nucleus. The typical signal for the olefinic H-6 of the steroidal skeleton was evident from the multiplet at $\delta 5.04$ integrating for one proton. The olefinic protons $(\mathrm{H}-22$ andH-23) appeared as characteristic downfield signals at $\delta 5.03$ and $\delta 5.18$ respectively in the ${ }^{1} \mathrm{H}$ NMR spectrum. Each of the signal was observed as double doublets $(\mathrm{J}=14.4,8.4$ $\mathrm{Hz}$ ) which indicated coupling with the neighboring olefinic and methane protons. The spectrum further revealed the signals at $\delta$ 0.67 and $\delta 1.00$ (three proton each) assignable to two tertiary methyl groups at $\mathrm{C}-13$ and $\mathrm{C}-10$, respectively. The ${ }^{1} \mathrm{H}$ NMR spectrum also showed two doublets centered at $\delta 0.80(\mathrm{~J}=7.4 \mathrm{~Hz})$ which could be attributed to the two methyl groups at C-25. The doublet at $0.91(\mathrm{~J}=6.4 \mathrm{~Hz})$ was demonstrative of a methyl group at C-20 (Table 5). 
Table 5: ${ }^{1} \mathrm{H}(400 \mathrm{MHz}),{ }^{13} \mathrm{C}(100 \mathrm{MHz})$ NMR Spectral Data of Compound MH-1 (Stigmasterol) In $\mathrm{Cdcl}_{3}$.

\begin{tabular}{|c|c|c|}
\hline Position & $\begin{array}{l}\text { Chemical Shifts }(\delta) \\
{ }^{1} \text { HNMR }\end{array}$ & ${ }^{13} \mathrm{C}$ NMR \\
\hline 1 & - & 37.2 \\
\hline 2 & - & 31.6 \\
\hline 3 & - & 71.8 \\
\hline 4 & - & 39.7 \\
\hline 5 & - & 140.7 \\
\hline 6 & $5.35(1 \mathrm{H}, \mathrm{s})$ & 121.6 \\
\hline 7 & - & 31.9 \\
\hline 8 & - & 31.6 \\
\hline 9 & - & 50.2 \\
\hline 10 & - & 36.5 \\
\hline 11 & - & 21.1 \\
\hline 12 & - & 39.8 \\
\hline 13 & - & 42.3 \\
\hline 14 & - & 56.8 \\
\hline 15 & - & 24.3 \\
\hline 16 & - & 28.2 \\
\hline 17 & - & 56.1 \\
\hline 18 & $0.79(3 \mathrm{H}, \mathrm{s})$ & 11.8 \\
\hline 19 & $0.95(3 \mathrm{H}, \mathrm{s})$ & 19.3 \\
\hline 20 & - & 34.0 \\
\hline 21 & $1.06(3 \mathrm{H}, \mathrm{d}, \mathrm{J}=8.0 \mathrm{~Hz}$ & 19.7 \\
\hline 22 & $5.03(1 \mathrm{H}, \mathrm{m})$ & 138.3 \\
\hline 23 & $5.18(1 \mathrm{H}, \mathrm{m})$ & 129.2 \\
\hline 24 & - & 45.9 \\
\hline 25 & - & 31.9 \\
\hline 26 & $0.86(3 \mathrm{H}, \mathrm{d}, \mathrm{J}=8.6 \mathrm{~Hz})$ & 19.0 \\
\hline 27 & $0.84(3 \mathrm{H}, \mathrm{d}, \mathrm{J}=7.5 \mathrm{~Hz})$ & 29.2 \\
\hline 28 & - & 25.3 \\
\hline 29 & $0.89(3 \mathrm{H}, \mathrm{d}, \mathrm{J}=8.0 \mathrm{MHz})$ & 12.1 \\
\hline
\end{tabular}

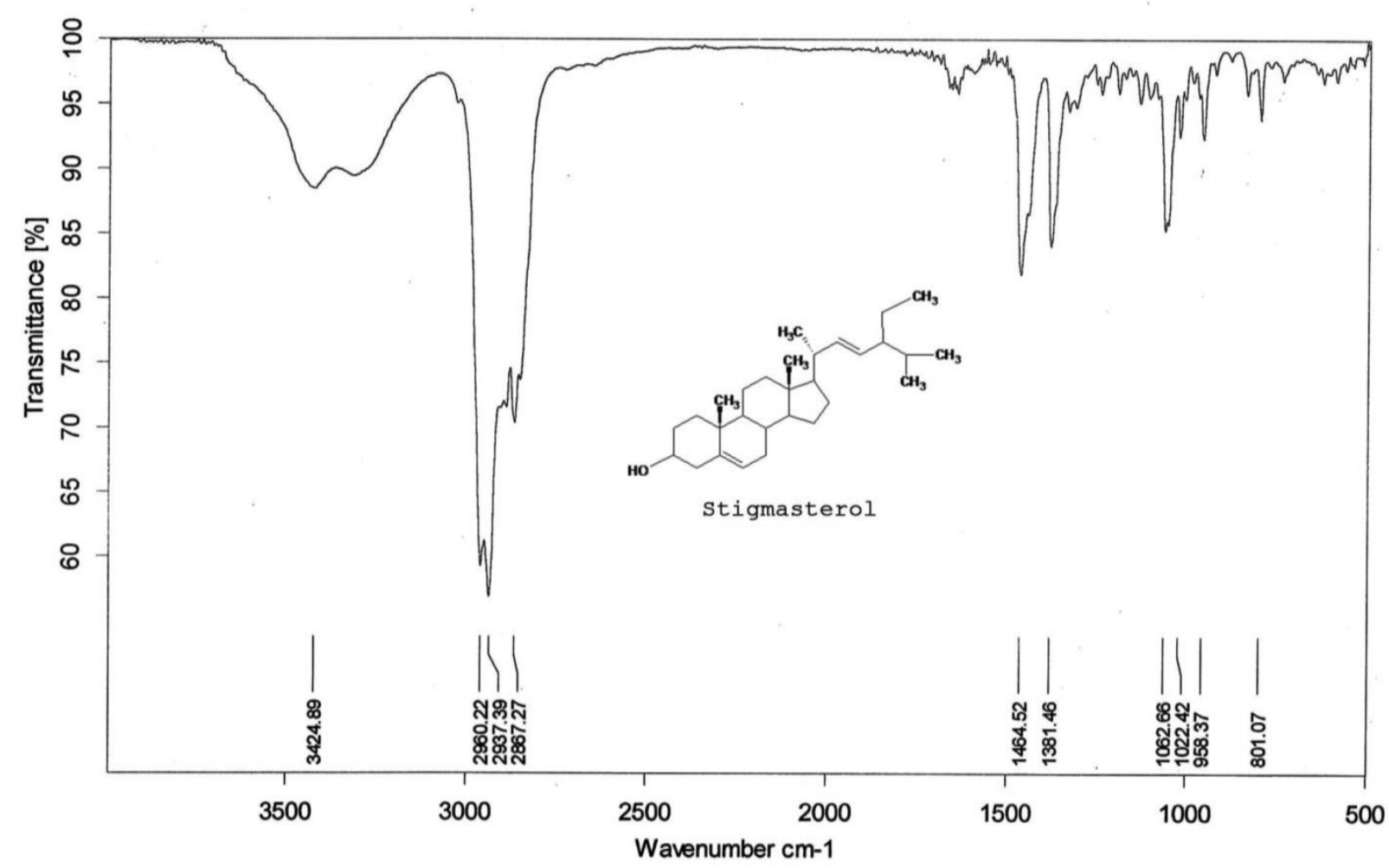




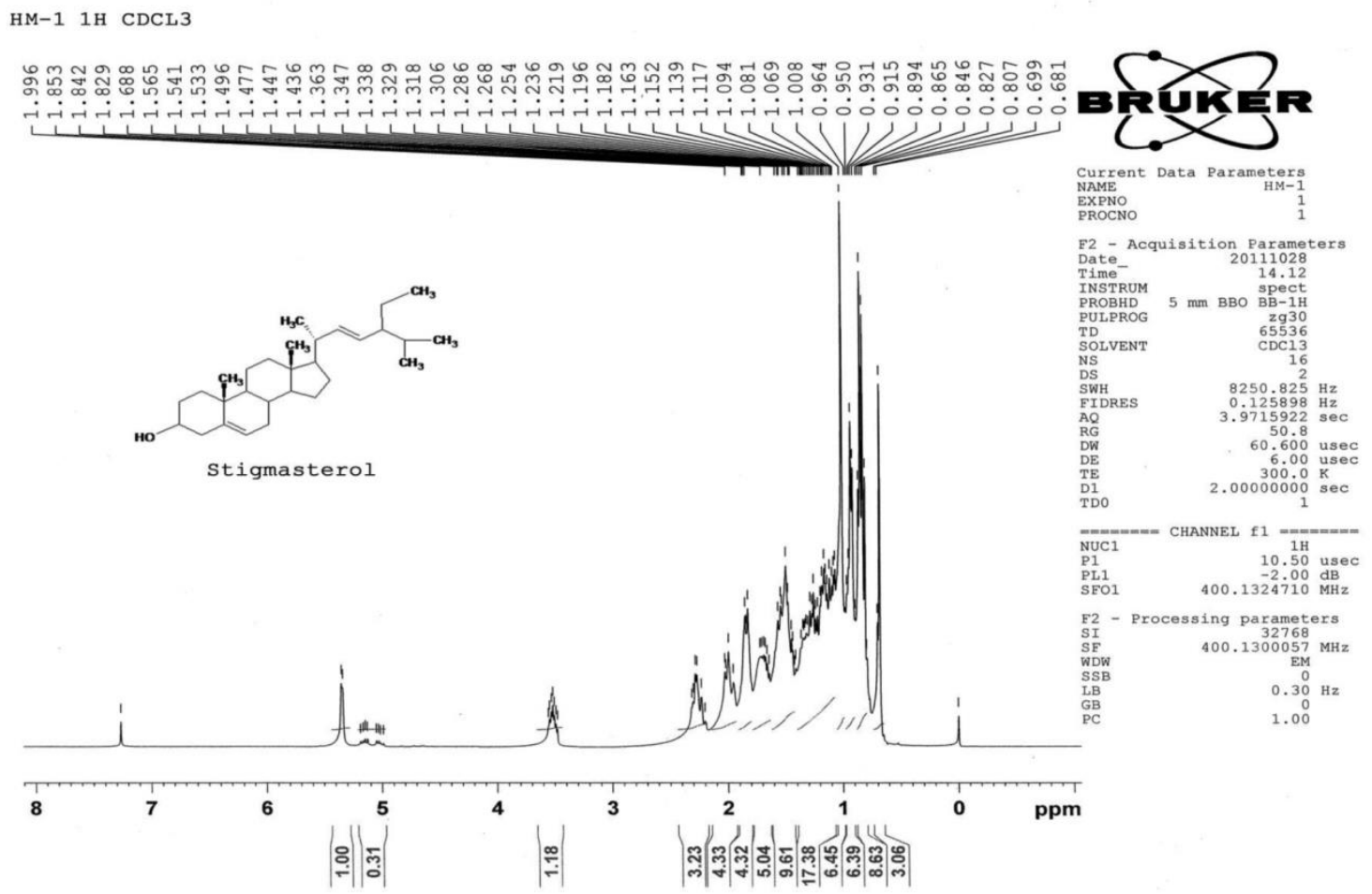

Fig.3: ${ }^{1} \mathrm{H}$ NMR Spectrum of the Compound HM-1.

HM-1 13C CDCL3

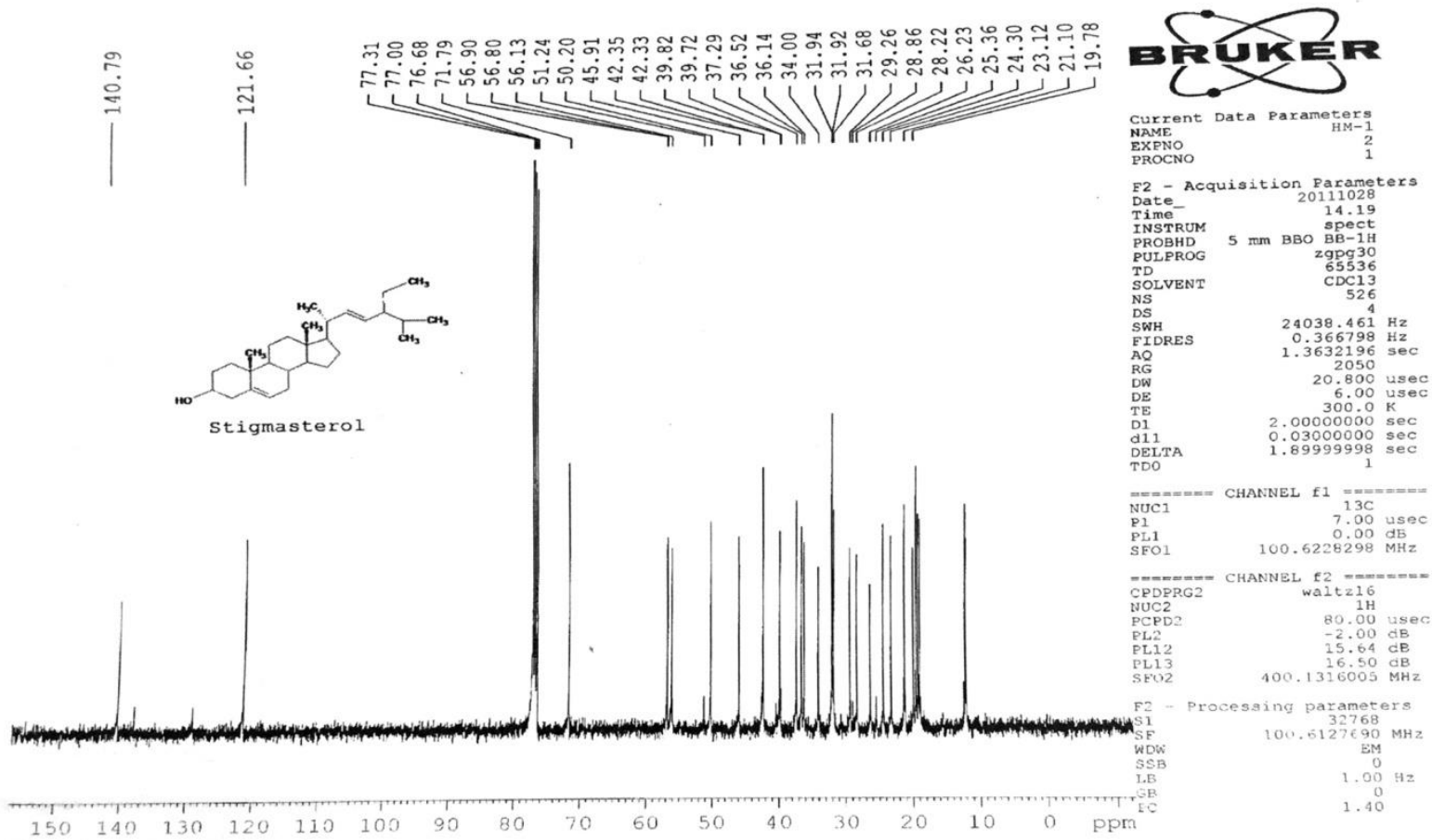

Fig.4: ${ }^{13} \mathrm{C}$ NMR Spectrum of the Compound HM-1.

The ${ }^{13} \mathrm{C}$ NMR spectrum (Fig 4) showed 29 carbons. Among 29 carbon resonances six were $\mathrm{CH}_{3}$, nine $\mathrm{CH}_{2}$, eleven $\mathrm{CH}$ and three quaternary carbons. These special features are in close agreement to those observed for stigmasterol (Khan, 1991). On the basis of NMR assignment and literature data, the compound was identified as stigmasterol (Pouchert and Behnke, 1968; Grecaet al., 1990; Habib et al., 2007).
3.4.2. Structural elucidation and characterization of compound HM-2

Compound HM-2 is color less or white needles with little impurities. The compound showed m.p. at $136-137^{\circ} \mathrm{C}$, with $\mathrm{R}_{\mathrm{f}}$ value: 0.50 (hexane; ethyl acetate, 93:07). The compound was freely soluble in hexane, chloroform, ether and chloroform and sparingly soluble in alcohol with molecular formula is $\mathrm{C}_{29} \mathrm{H}_{50} \mathrm{O}$. The compound gave positive color reaction with Liebermann Burchard reaction and Solkowski reaction test for steroids. 
IR spectrum showed a strong and broad absorption band at $3438 \mathrm{~cm}^{-1}$, which corresponded to $-\mathrm{OH}$ stretching. Two bands were seen at 2931 and $2854 \mathrm{~cm}^{-1}$, which corresponded to $\mathrm{C}=\mathrm{C}$ stretching vibrations. Absorption bands were seen at 1462 and $1378 \mathrm{~cm}^{-1}$, which corresponded to $\mathrm{C}-\mathrm{O}$ stretching vibrations (Fig $5)$.

The ${ }^{1}$ HNMR spectrum (Fig 6) showed the presence of 6 methyl groups at $\delta 0.8-1.25$ and 6 methylenic protons at $\delta 1.2$ to 2.04 The proton attached to C-3 carbon bearing the hydroxyl group appeared $\delta 3.52$ as a multiplet. The protons attached to the olefenic carbon appeared to $\delta$ value of 5.1 as multiplet. The ${ }^{1} \mathrm{H}$ NMR spectrum ofthe compound $\mathrm{KCHE}-8\left(400 \mathrm{MHz}, \mathrm{CDCl}_{3}\right)$ exhibited a broad doublet at $\delta 5.36(1 \mathrm{H}, \mathrm{d}, \mathrm{J}=5.1 \mathrm{~Hz})$ attributed to be a double bonded proton typical for a multiplet at $\delta 3.55(1 \mathrm{H}, \mathrm{m})$ integrated for one proton which could be H-3 of a steroidal skeleton. Other sig- nals appeared between $\delta 0.9-\delta 2.4$ was due to the methylene and methane protons.

The ${ }^{13} \mathrm{C}$ NMR spectra (Fig 7) showed the presence of 6 quartets, 11 triplets, 9 doublets and three singlets corresponding to 6 methyl, 11 methylene, 9 methine and 3 tertiary carbons. The presence of two $\mathrm{C}=\mathrm{C}$ was inferred by the presence of a singlets and 3 doublets at $\delta 140.85$ and 121.72 . The mass spectrum showed a peak at 414(molecular ion peak) which corresponds to the molecular weight, a peak at $396\left(\mathrm{M}-\mathrm{H}_{2} 0\right)^{-}$which confirmed the presence of hydroxyl group (Table 6). Mass spectrum indicates $\left(\mathrm{M}^{+} 414\right)$ the molecular formula $\mathrm{C}_{29} \mathrm{H}_{50} \mathrm{O}$. Comparison of ${ }^{1} \mathrm{H}$ and ${ }^{13} \mathrm{C}$ NMR data with literature reports and Co-TLC identified it as $\beta$-sitosterol (Ahmad et al., 1992). These features were in close agreement with those of $\beta$-sitosterol reported in the literature (Hill et al., 1999).

Table 6: ${ }^{1} \mathrm{H},(400 \mathrm{MHz}){ }^{13} \mathrm{C}$ NMR (100 MHz) Spectral Data of Compound B-Sitosterolin $\mathrm{Cdcl}_{3}$.

\begin{tabular}{lll} 
& Chemical Shifts $(\delta)$ & ${ }^{13}$ C NMR \\
\hline Position & ${ }^{1}$ HNMR & 36.1 \\
\hline 1 & - & 31.7 \\
2 & $2.03(2 \mathrm{H}, \mathrm{m})$ & 71.8 \\
3 & $3.24(1 \mathrm{H}, \mathrm{m})$ & 42.4 \\
4 & - & 140.8 \\
5 & - & 121.7 \\
6 & $5.28(1 \mathrm{H}, \mathrm{s})$ & 29.3 \\
7 & - & 31.9 \\
8 & - & 50.2 \\
9 & - & 36.5 \\
10 & - & 21.1 \\
11 & - & 40.4 \\
12 & - & 42.4 \\
13 & - & 56.8 \\
14 & - & 24.3 \\
15 & - & 29.3 \\
16 & - & 56.8 \\
17 & - & 12.0 \\
18 & $0.68(3 \mathrm{H}, \mathrm{s})$ & 12.2 \\
19 & $1.01(3 \mathrm{H}, \mathrm{s})$ & 34.0 \\
20 & - & 21.1 \\
21 & - & 34.0 \\
22 & - & 28.2 \\
23 & $5.02(1 \mathrm{H}, \mathrm{dd}, \mathrm{J}=15.2,8.6 \mathrm{~Hz})$ & 51.2 \\
24 & - & 26.2 \\
25 & - & 19.1 \\
26 & $0.83(3 \mathrm{H}, \mathrm{d}, \mathrm{J}=6.6 \mathrm{~Hz})$ & 19.8 \\
27 & $0.83(3 \mathrm{H}, \mathrm{d}, \mathrm{J}=6.6 \mathrm{~Hz})$ & 24.3 \\
28 & - & 11.9 \\
29 & $0.84(3 \mathrm{H}, \mathrm{m})$ & \\
& & \\
\end{tabular}




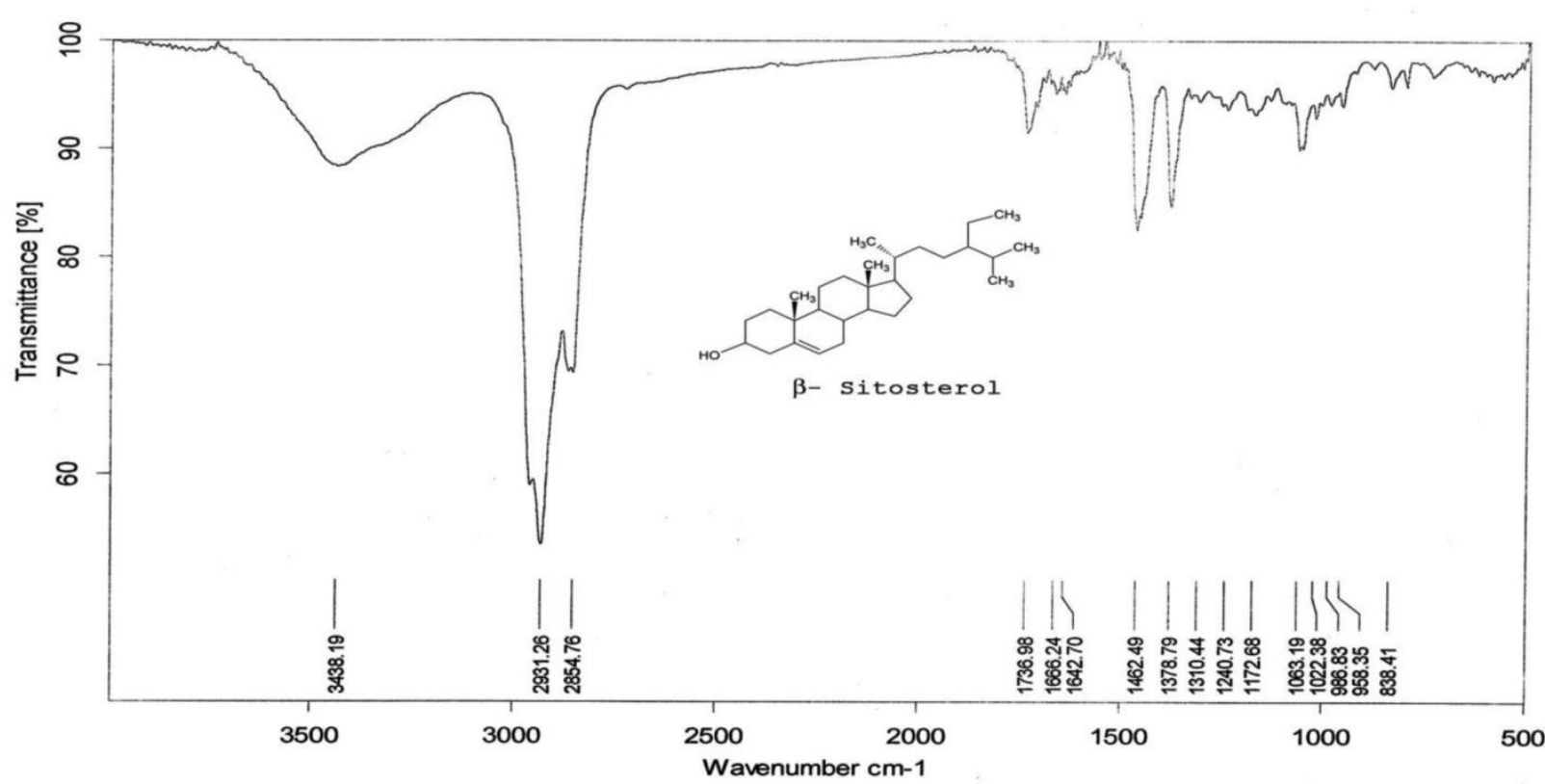

\begin{tabular}{|l|l|l|}
\hline C:IProgram FilesIOPUS_65IMEASUHM-2 & HM-2 $\quad$ Instrument type and / or accessory & 10/11/2011 \\
\hline
\end{tabular}

Fig.5:IR Spectrum of Compound HM-2.

HM-2 1H CDCL3

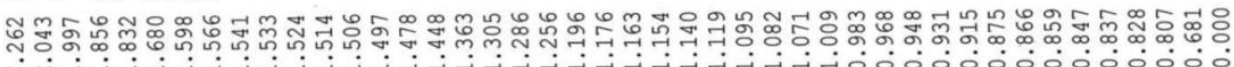

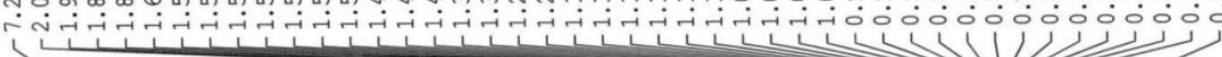

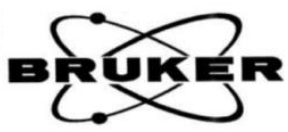

Current
NAME
EXPNO

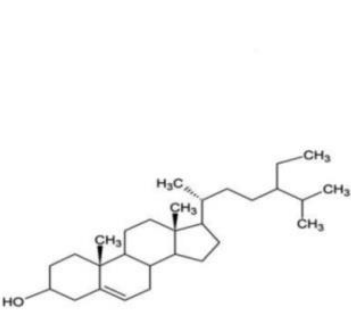

B- sitosterol
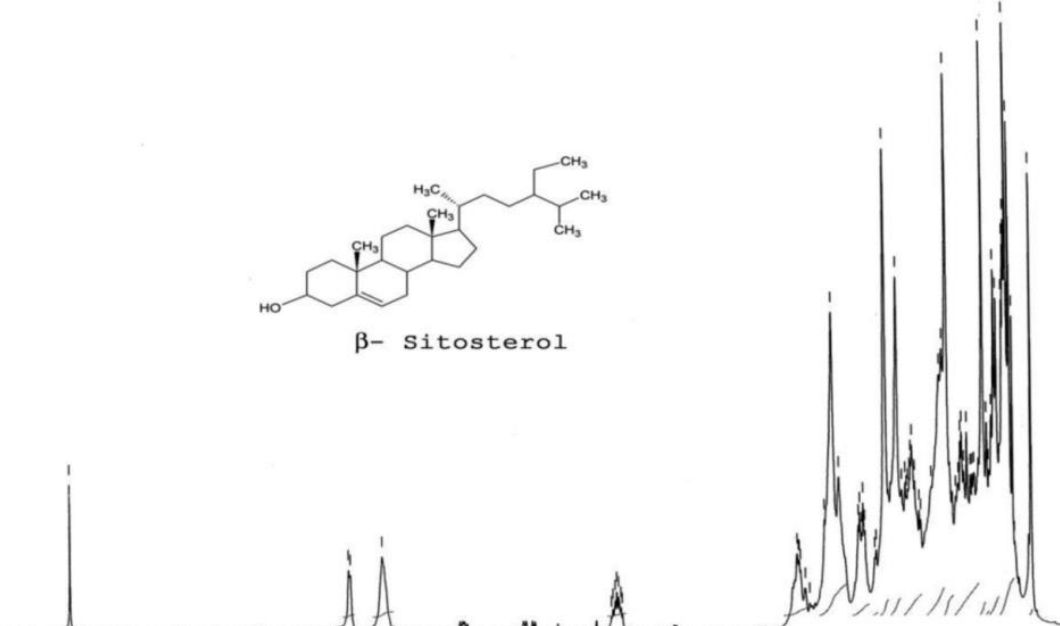

F2- Acquisition Parameters
Date_- 20111028
Time- 12,37

PROBHD
PULPROG

NS

$\begin{array}{lr}\text { DS } & 8250.825 \mathrm{~Hz} \\ \text { FID } & 0.125898 \mathrm{~Hz} \\ \text { AOD } & 3.9715922 \mathrm{sec} \\ \text { RG } & 8.62\end{array}$

2

60.600 usec
6.000 usec

D1
TDO

$2.00000000 \mathrm{Kec}$

$\begin{array}{ll}\text { NUC1 } & \\ \text { P1 } & 10.50 \text { usec }\end{array}$

PL1 $\quad-2.00 \mathrm{~dB}^{\mathrm{PL} 1}$

$\begin{array}{lr}\text { F2 } & \text { - Processing parameters } \\ \text { SI } & 32768 \\ \text { SE } & 400.1300077 \mathrm{MHz}\end{array}$

ND
SS
GB
GC

GB

$0.30 \mathrm{~Hz}$

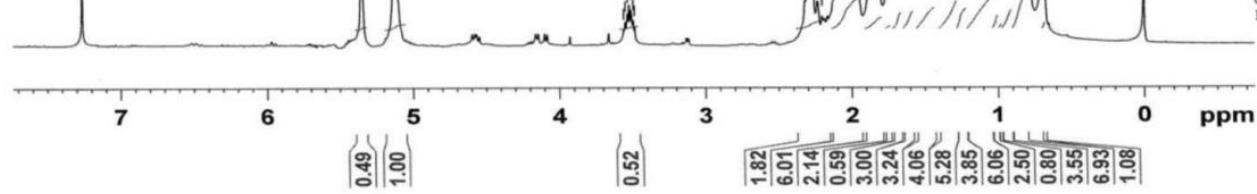

Fig. 6: ${ }^{1} \mathrm{HNMR}$ Spectrum of Compound HM-2. 


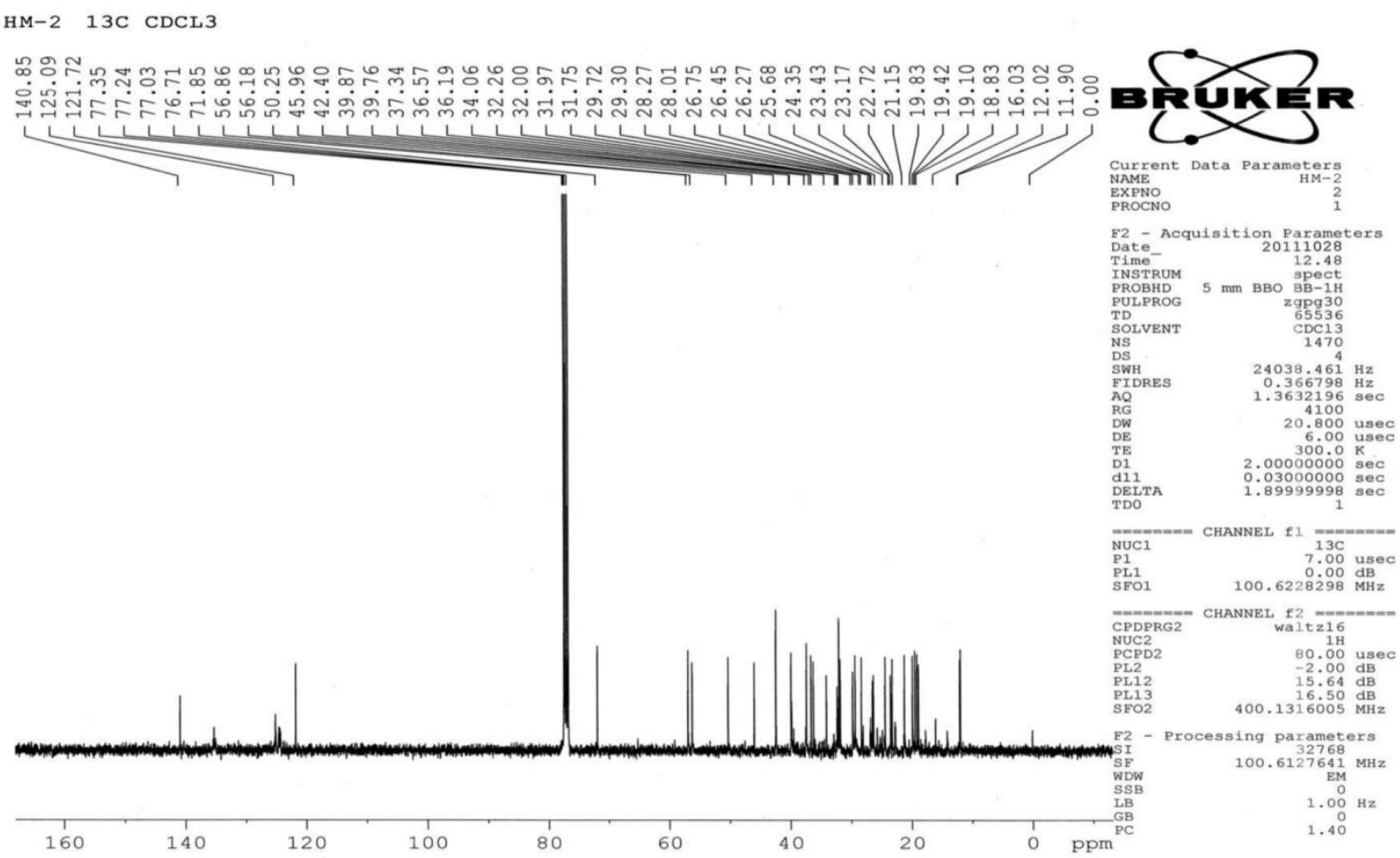

Fig.7: ${ }^{13} \mathrm{C}$ NMR Spectra of Compound HM-2.

\section{Discussion}

The remedies available in modern medicine provide only symptomatic relief, without any significant changes to the etiological causes of the disease process (Okada and Okada, 1998; Pen-DerDuh, 1998), there are increasing harmful effects of modern medicines and diseases causing microorganisms getting resistance towards the drugs using in the treatment of diseases (Aktar et al., 2009; Ganga Rao et al., 2013). Moreover, as many therapeutic agents are known to cause conditions such as liver cirrhosis and fulminate hepatic failure, the development or identification of new molecules effective in treating or preventing hepatic damage remains a challenge in the field of drugs development (Ajith et al., 2007; Kappus, 1991; Khan and Shahidi, 2001). All these problems, insisting the scientists to search for the discovery of new drugs with more efficacy, less side effects and low economic costs. The present study aimed to evaluate the antioxidant and hepatoprotective capacity of the $H$. mystax aerial parts extracts and results reveal that the plant posses significant capacity in reduction of free radicals and significant restoration of the altered biochemical parameters towards normal in TAA intoxicated rat i.e. TAA causes the hepatic injury and subsequently to its failure, thus severely affecting the body's entire metabolism by producing the different free radicals formation in the cells metabolism process (Charlotte et al., 2013; PavlaStan ková et al., 2010; James et al., 2014; Stephen et al., 2013). The effects of the tested extracts were increased as concentration was increases in ameliorate the levels of free radicals, enzymes levels due to intoxication and also the presence of compounds stigamsterol and $\beta$-sitosterol in the selected plant from the hydroalcoholic extract which are previously reported different biological activities (Hogg John, 1992; Salvador et al., 2004; Panda et al., 2009; Gabay et al., 2010), so further investigations are needed to isolate novel bioactive compounds.

\section{Conclusion}

It could be conclude that $H$. mystax have the capacity in reduction of free radicals produced in the body due to different physiological mechanisms either normal or abnormal conditions (Diseases).The isolated compounds stigamsterol and $\beta$-sitosterol are evidence about the presence of different bioactive molecules in $H$. mystax.Further research is need to evaluate more pharmacological activities and in isolation of the more bioactive compounds.

\section{Acknowledgements}

The authors are acknowledging to the authorities of Andhra University in providing the necessary facilities and also to the Rajiv Gandhi National Fellowship (RGNF)-UGC, New Delhi for financial support which enabled me to successfully complete the research.

\section{Conflicts of interest}

There are no conflicts of interest.

\section{References}

[1] Ahmad, W., Ahmad, Z., and Malik, A. (1992). Stigmasterylgalactoside from Rhynchosia minima. Phytochem,31: 4038.http://dx.doi.org/10.1016/S0031-9422(00)97583-6.

[2] Ajith, T. A, Hema, U., and Aswathy, MS. (2007). Zingiber officinale Roscoe prevents acetaminophen induced acute toxicity by enhancing hepatic antioxidant status. Food ChemToxicol, 45: $2267-$ 2272.http://dx.doi.org/10.1016/j.fct.2007.06.001.

[3] Alqasoumi, S. I., Al-Dosari, M. S., Al-Sheikh, A. M., and AbdelKader, M. S. (2009). Evaluation of the hepatoprotective effect of Fumariaparviflora and Momordica balsamica from Saudi folk medicine against experimentally induced liver injury in rats. Res $\mathbf{J}$ Med Plants, 3: 9-15.http://dx.doi.org/10.3923/rjmp.2009.9.15.

[4] Anita Murali., Purnima Ashok., and Madhavan, V. (2011). In vitro antioxidant activity and HPTLC Studies on the roots and rhizomes of Smilax zeylanica. (Smilacaceae). Int J Pharm PharmSci, 3(1): 192-195.

[5] Ashok, S. K., Somayaji, S. N., and Bairy, K. L. (2001). Hepatoprotective effects of Ginkgo bilobaagainst carbon tetrachloride induced hepatic injury in rats. Indian J Pharmacol, 33 (suppl. 2): 260-266.

[6] Balandrin, M. F,Klocke, J. A,Wurtele, E. S, and Bollinger, W. H. (1985). Natural plant chemicals: Sources of Industrial and Medici- 
nal materials $\quad$ Science $\quad 228$ : 1154 1160.http://dx.doi.org/10.1126/science.3890182.

[7] Bandaranayake, W. M. (2002). Bioactivities, bioactive compounds and chemical constituents of mangrove plants. Wet EcolManag, 10: 421-2.http://dx.doi.org/10.1023/A:1021397624349.

[8] Braca, A, Fico, G,Morelli, I, De Simone, F, Tome, F, and De Tommasi, N. (2003). Antioxidant and free radical scavenging activity of flavonol glycosides from different Aconitum species. J Ethnopharmacol, $\quad 86: \quad$ 63-67.http://dx.doi.org/10.1016/S03788741(03)00043-6.

[9] Clark, A. M, and Hufford, C. D. (1993). Discco and development of novel prototype antibiotics for opportunistic infections related to the acquired immunodeficiency syndrome. In: Human Medical Agents from Plants. American Chemical Society (ACS Symposium series 534), Washington, D.C. 228-241.

[10] Dorğru-Abbasoğlu, S, Kanbağli, O. Balkan, J, Cevikbaş, U,.AykaçTokerl, G, and Uysall, M. (2000). The protective effect of taurine against thioacetamide hepatotoxicity of rats. Hum. Exp. Toxicol, 20: 23-27.http://dx.doi.org/10.1191/096032701673031525.

[11] Elizabeth, K., and Rao M. N. A. (1990). Oxygen radical scavenging activity of curcumin. Int J Pharm,58: 237240.http://dx.doi.org/10.1016/0378-5173(90)90201-E.

[12] Gabay, O,. Sanchez, C, Salvat, C, Chevy, F, Breton, M, Nourissat, G, Wolf, C, Jacques, C, and Berenbaum, F. (2010). Stigmasterol: a phytosterol with potentialanti-osteoarthritic properties. Am J ClinNutr, 18 (1): 106-116. http://dx.doi.org/10.1016/j.joca.2009.08.019.

[13] Ganga Rao, B., VenkateswaraRao, Y., and MallikarjunaRao, T.(2013).Hepatoprotective and antioxidant capacity of Melochiacorchorifolia Extracts, Asian Pacific Journal of Tropical Medicine, 6 (7): 412-420.

[14] Greca, M. D,. Monaco,M,.andPrevitra, L. (1990). Stigmasterol from Typha latifolia. Journal of Natural Products, 53: 14301434.http://dx.doi.org/10.1021/np50072a005.

[15] Gupta, M. B,.Nath, R., Srivastava, N,.Shanker, K,.Kishor, K,.and Bhargava, K. P. (1980). Anti-inflammatory and antipyretic activities of beta-sitosterol. PlantaMedica, 39: 157163.http://dx.doi.org/10.1055/s-2008-1074919.

[16] Habib, M. R.,Nikkon, F,.Rahman, M..Haque, M. E,.andKarim, M. R. (2007). Isolation of stigmasterol and beta-sitosterol from methanolic extract of root bark of Calotropis gigantea (Linn). Pakistan J BiolSci, 10: 4174.http://dx.doi.org/10.3923/pjbs.2007.4174.4176.

[17] Hill, R. A,.Kiok, D. K,.Makein, H. L. J,.andMusphy, G. H. (1999). Dictionary of Steroids. Chapman and Hall, Great Britain.

[18] Hogg John, A. (1992). Steroids, the steroid community, and Upjohn in perspective: A profile of innovation. Steroids.57 (12): 593616.http://dx.doi.org/10.1016/0039-128X(92)90013-Y.

[19] Jamshidzadeh, A., and Nikmahad, H,. (2006). Hepatoprotective effects of Fumaria parviflora $\mathrm{L}$. on $\mathrm{CCl}_{4}$-induced hepatotoxicity. J Med Plants, 5: 34-9.

[20] Kappus, H,. (1991). Lipid peroxidation mechanism and biological relevance. In: Aruoma OI, Halliwell B, Editors. Free radicals and food additives. London UK: Taylor and Francis, 59-75.

[21] Khan, R. I. Natural Product. A laboratory guide, 2ndEdn. (Academic Press, N.Y. USA). 1991

[22] Khan, M. A,. and Shahidi, F. (2001). Effect of natural and synthetic antioxidants antioxidants on the oxidative stability of borage and evening primrose triglycerides. Food Chem, 75: 431437.http://dx.doi.org/10.1016/S0308-8146(01)00232-1.

[23] Kroschwitz, J. I,.and Howe-Grant, M. (1992). Kirk-Othmer encyclopedia of chemical Technology, 2: 893 .

[24] Mangipudy, R. S,.Chanda, S,.andMehendale, H. M. (1997). Tissue repair response as a function of dose in thioacetamide hepatotoxicity. Environ Health Persp, 260-267.

[25] Mc Cord, J. M,.andFridovich, I. (1969). Superoxide dismutase: an enzymatiic function for erythrocuprein (hemocuprien). J BiolChem, 244: 6049-6055.

[26] Nambiar, V. P. K. (1995). Indian Medicinal Plants a compendium of 500 Medicinal plants. Orient Longman Private Ltd.

[27] Newman, D. J,.Cragg, G. M,. and Snader, K. M. (2000). The influence of natural products upon drug discovery. Nat Prod Res, 17 215-234.http://dx.doi.org/10.1039/a902202c

[28] Okada, Y,.and Okada, M. (1998). Scavenging effect of soluble proteins in broad beans of free radicals and oxygen species. J Agric Food Chem, 46: 401-406.http://dx.doi.org/10.1021/jf9704701.

[29] Padel, S. B,.Murty, P. P,.Rao, D. S,.andVenkaiah, M. (2010). Ethnomedicinal plants from Paderu Division of Visakapatnam District, A.P. India.J Phytol, 2(8): 70-91.

[30] Panda, S,.Jafri, M,.Kar, A,.andMeheta, B. K. (2009). Thyroid inhibitory, antiperoxidative and hypoglycemic effects of stigmasterol isolated from Butea monosperma. Fitoterapia, $80(2)$ : $123-$ 126.http://dx.doi.org/10.1016/j.fitote.2008.12.002.

[31] Pen-Der-Duh X. (1998). Antioxidant activity of burdock (Arctiumlappa Linne.): it's scavenging effect on free radical and active $\begin{array}{llllll}\text { oxygen. J Am } & \text { Oil Soc, } & \text { 75: }\end{array}$ 461.http://dx.doi.org/10.1007/s11746-998-0248-8.

[32] Pouchert, C. J,and Behnke, J. (1968). The Aldrich Library of $13 \mathrm{C}$ and 1H FT-NMR Spectra, (Aldrich Piblication, USA). 1-3: 569.

[33] Pullaiah, T,. and Chennaiah, E. (1997). Flora of Andhra Pradesh Scientific Publishers, Jodhpur, India.

[34] RajanadaSwamy, T,.MallikarjunaRao, T,. and Ganga Rao, B (2016). Phytochemical analysis and antibacterial activity of $\mathrm{Hu}$ gonia mystax aerial parts. International Journal of Green Pharmacy, 10(1): $1-5$

[35] Salvador, M. J,Zucchi, O. L. A. D,.Candido, R. C,. Ito, I. Y,.and Dias, D. A. (2004). In vitro antimicrobial activity of crude extracts and isolated constituents of Alternanthera maritima (Amaranthaceae). Pharm Biol, 42: 138148.http://dx.doi.org/10.1080/13880200490511954.

[36] Santapau, H,. Henry, A. N. (1983). A Dictionary of flowering plants in India. (Council of Scientific and Industrial Research (CSIR), New Delhi). 103

[37] Sengupta, M,. Sharma, G. D,.and Chakraborty, B. (2011). Hepatoprotective and immunomodulatory properties of aqueous extract of Curcuma longa in carbon tetra chloride intoxicated Swiss albino mice. Asian Pac J Trop Biomed, 1(3): 193 199.http://dx.doi.org/10.1016/S2221-1691(11)60026-9.

[38] Stockwell, C. (1988). Nature's pharmacy. (Century Hutchinson Ltd. London, United Kingdom).

[39] Thomson, W. A. R. (1978). Medicines from the Earth. Maidenhead. (McGraw-Hill Book Co. United Kingdom).

[40] Charlotte M. Witmer, Robert R. Snyder, David J. Jollow,. George F. Kalf, and James J. Kocsis. (2013). Biological Reactive Intermediates IV: Molecular and Cellular Effects and Their Impact on $\mathrm{Hu}-$ man Health. Springer Science \& Business Media.

[41] PavlaStan`ková,. Otto Kuc`era,.HalkaLotková,.TomášRoušar, René Endlicher, and ZuzanaC`ervinková. (2010). the toxic effect of thioacetamide on rat liver in vitro. Toxicology in vitro, 24: 20972103.http://dx.doi.org/10.1016/j.tiv.2010.06.011.

[42] James P. Hamilton,. James J. Potter,Laharikoganti,. Stephen J. Meltzer and Esteban Mezey. (2014). Effects of vitamin D3 stimulation of thioredoxin-interacting protein in hepatocellular carcinoma. Hepatol Res. 44(13): 13571366.http://dx.doi.org/10.1111/hepr.12302.

[43] Stephen W.G. Tait.and Douglas R. Green. (2013). Mitochondrial Regulation of Cell Death. Cold Spring HarbPerspect Biol. 5(9): a008706.http://dx.doi.org/10.1101/cshperspect.a008706. 